\title{
On approximate Cobb-Douglas production functions
}

\author{
MARIA ILCA and DORIAN POPA
}

\begin{abstract}
.
We introduce a new type of production function, called approximate Cobb-Douglas function, by a perturbation of Euler's partial differential equation characterizing homogeneous function. We show that for every approximate Cobb-Douglas function, there exist an exact Cobb-Douglas function near it.
\end{abstract}

\section{REFERENCES}

[1] Carter, S., On the Cobb-Douglas and all that': The Solow-Simon correspondence over the neoclassical aggregate production function, Journal of Post Keynesian Economics (to appear)

[2] Charnes, A., Cooper, W. W. and Schinnar, A. P., A theorem on homogeneous functions and extended Cobb-Douglas forms, Proc. Natl. Acad. Sci. USA, 73 (1976), 3747-3748

[3] Cîmpean, D. S. and Popa, D., Hyers-Ulam stability of Euler's equation, Appl. Math. Lett., 24 (2011), 1539-1543

[4] Cobb, C. and Douglas, P., A theory of production, American Economic Review, 18 (1928), 139-165

[5] Cronin, B. and Gudin, M., Information and productivity: A review of research, International Journal of Management, 6 (1986), 85-101

[6] Felipe, J., Aggregate production function and the measurement of infrastructure productivity; A reassessment, Eastern Economic Journal, 31 (2005), 427-446

[7] Felipe, J. and Holz, C. A., Why do aggregate production function work? Fisher's simulations, Shaikh's identity and some new results, International Review of Applied Economics, 15 (2001), 261-285

[8] Hyers, D. H., Isac, G. and Rassias, Th. M., Stability of Functional Equations in Several Variables, Birkhäuser, Basel, 1998

[9] Labini, P. S., Why the interpretation of Cobb-Douglas production function must be radically changed, Structural Change and Economics Dynamics, 6 (1995), 485-504

[10] Menderhausen, H., On the significance of Professor Douglas' Production function, Econometrica, 6 (1938), 143-153

[11] Pressman, S., What is wrong with the aggregate production functions, Eastern Economic Journal, 31 (2005), $421-426$

[12] Shaikh, A., Nonlinear dynamics and Pseudo production functions, Eastern Economic Journal, 31 (2005), 447-466

[13] Shephard, R., Theory of Cost and Production Functions, Princeton University Press, 1970

[14] Simon, H. and Levy, F., A note on Cobb-Douglas function, Review of Economic Studies, 30 (1963), 93-94

[15] Teo, T. S. H., Wong, P. K. and Chia, E. H., Information technology (IT) investment and the role of a firm; an exploratory study, International Journal of Management, 20 (2000), 269-286

[16] Thompson, A., Economics of the Firm, Theory and Practice, Prentice Hall, 1981

[17] Vîlcu, G. E., A geometric perspective of the generalized LD-Cobb-Douglas production function, Appl. Math. Lett., 24 (2011), 777-783

DePARTMENT OF MANAGEMENT

AVRAM IANCU UNIVERSITY

Ilie MaCelaru 5, Cluj-NAPOCA, Romania

Received: 03.09.2012; In revised form: 14.05.2013; Accepted: 21.06.2013

2010 Mathematics Subject Classification. 35B20, 35B35, 39B82.

Key words and phrases. Approximate Cobb-Douglas function, homogeneous functions, Euler's equation, stability.

Corresponding author: Dorian Popa; Popa.Dorian@math.utcluj.ro 
Department of Mathematics

TECHNICAL UNIVERSITY OF CLUJ-NAPOCA

Memorandumului 28, 400114 Cluj-NAPOCA, Romania

E-mail address: Popa.Dorianemath.utcluj.ro 